\title{
Phylogeography and the conservation of coral reef fishes
}

\author{
L. A. Rocha $\cdot$ M. T. Craig $\cdot$ B. W. Bowen
}

Published online: 24 July 2007

(c) Springer-Verlag 2007

\section{Erratum to: Coral Reefs}

\section{DOI 10.1007/s00338-007-0261-7}

Unfortunately, the caption text for Fig. 2 is incorrect. The correct caption is given below:

Fig. 2 Cryptic species detected by genetic markers. a Halichoeres maculipinna from the Caribbean, and c Halichoeres penrosei from Brazil are separated by a mean sequence divergence of $6.5 \%$ at the cytochrome $b \mathrm{mtDNA}$ gene. b Rypticus saponaceus from Brazil, and d West Africa are separated by a mean sequence divergence of $4.1 \%$ at the cytochrome $b$ mtDNA gene

The online version of the original article can be found under doi:10.1007/s00338-007-0261-7.

L. A. Rocha $(\varangle) \cdot$ M. T. Craig $\cdot$ B. W. Bowen

Hawaii Institute of Marine Biology,

University of Hawaii, P.O. Box 1346,

Kaneohe, HI 96744, USA

e-mail: RochaL@hawaii.edu 